\title{
Standardization of Plant Geometry for Productivity Enhancement of Melia dubia Cav. under Agro-Forestry Pulpwood Plantation
}

\author{
K. Jayakumar ${ }^{1 *}$ and P. Sudhakar ${ }^{2}$ \\ ${ }^{1}$ Department of Plantation, TNPL, Kagithapuram, Karur- 639136, Tamil Nadu, India \\ ${ }^{2}$ Department of Agronomy, Faculty of Agriculture, Annamalai University, \\ Annamalainagar- 608002, Tamil Nadu, India \\ *Corresponding author
}

\section{A B S T R A C T}

\section{Keywords}

Melia dubia, Spacing, Stand volume, Yield, Bio mass, Carbon sequestration

Article Info

\section{Accepted:}

10 November 2020 Available Online: 10 December 2020
The fast growing native species Melia dubia is gaining momentum among the farmers for raising commercial plantations. To standardize the plant geometry, an important silvicultural package for raising Melia dubia as commercial/ agro-forestry plantation, a trial was conducted in the TNPL's Plantation Research Block, Kagithapuram, Karur, Tamil Nadu. Melia dubia clonal plants var.GK-10 was used as test variety. The trial was conducted in monoculture block plantation system. Four spacing i.e. $1.5 \mathrm{~m} \mathrm{X} 1.5 \mathrm{~m} \mathrm{(4444}$ plants ha $\left.{ }^{-1}\right), 2 \mathrm{~m} \mathrm{X} 2 \mathrm{~m}\left(2500\right.$ plants $\left.\left.\mathrm{ha}^{-1}\right), 2.0 \mathrm{~m} \mathrm{X} \mathrm{2.5m} \mathrm{(2000} \mathrm{plants} \mathrm{ha}{ }^{-1}\right)$ and $3.0 \mathrm{~m} \mathrm{X} 1.5 \mathrm{~m}$ (2222 plants $\mathrm{ha}^{-1}$ ) were adopted in this study. The experiment was conducted in randomized block design and replicated four times. Bio metric observations viz. GBH, Height, stand volume, total biomass and amount of carbon sequestration was recorded at periodic interval of once in six months. The results revealed that although the individual trees performed superior in recording higher values of growth and yield attributes in wider spaced plots, closer spacing with $1.5 \mathrm{~m} \mathrm{X} 1.5 \mathrm{~m}$ (4444 plants ha $\left.{ }^{-1}\right)$ and $2 \mathrm{~m} \mathrm{X} 2 \mathrm{~m}$ (2500 plants $\mathrm{ha}^{-1}$ ) recorded significantly higher stand volume and yield per ha as compared to wider spacing plantations. The maximum biomass production and carbon sequestration were also recorded higher with the closer spacing plantations.

\section{Introduction}

The National Forest Policy (2014) emphasis on production of wood based raw materials required for agro based industrial purpose on farmer's field. Pulp and paper industries are one of the major industrial sector consuming large volumes of wood products as their raw materials. Due to the limitations of land availability and relaying to large extent on wood based fiber, paper industries in have entered in contract farming system with farmers for raising commercial/ agro- forestry plantations even before the enforcement of National Forest Policy 2014.

At present, exotic species viz. Eucalyptus, Casuarina, Dalbergia sissoo, Leucenea and 
Poplulus were dominantly used agro-forestry plantations by pulp and paper industries (Chauhan et al., 2018). These exotic species grow well in certain agro-climatic areas and requires specific climatic conditions. Melia dubia is one of the indigenous fast growing alternate pulpwood species adoptive to wide agro-climatic conditions of India (Thakur et al., 2017). Melia dubia belongs to the family Meliaceae, is an economically important tree species known as Malabar Neem. Wood of Melia dubia is highly suitable raw material for wood based industries like paper and plywood industries owing to its natural anti- termite property, high pulp recovery and fiber strength (Saravanan et al., 2013). The industrial and ecological importance of Melia dubia has encouraged the farmers to take large scale plantations with various intercrops (Parthiban et al., 2009). The farmers usually plant Melia dubia seedling plants in bunds and at block plantation at various spacing. Using the best genetic source for any species for a given region is the key to enhance the productivity of agro-forestry system (Tak and Jindal, 2014). The choice of planting density is the primary silvicultural decision, which influences the total stand volume, quality and quantity of wood products throughout the rotation (Patil et al., 2017).

Therefore, keeping in view of the above facts, the present investigation was undertaken to standardize the spacing of Melia dubia in block plantation under agro-forestry system. The foremost aim of the study was to improve the growth, volume and productivity of Melia dubia (var.GK.10) and to find the maximum carbon sequestration capacity with this short rotation pulpwood species.

\section{Materials and Methods}

The present investigation was accomplished in TNPL's Plantation Research Block, Kagithapuram, Karur, Tamil Nadu with the physiographic location of Latitude N1 ${ }^{\circ} 03.448 '$, Longitude E $077^{\circ} 59.444^{\prime}$ and altitude of $459 \mathrm{ft}$ above mean sea level (MSL) during January 2018 to July 2020. The soil of the experimental site was red sandy loam with the nutritional content of $182 \mathrm{~kg}$ nitrogen, 16 $\mathrm{kg}$ phosphorus and $395 \mathrm{~kg}$ potassium per ha. The Melia dubia clonal variety GK-10, having superior genetic features, fast growing and high yielding capacity was selected as test variety and multiplied using mini cutting technique at Clonal Propagation and Research Center (CPRC) of Tamilnadu Newsprint and Papers Limited (TNPL), Karur. Mini cuttings of about $10 \mathrm{~cm}$ height were taken from mother clonal plants and planted in suitable media at mist chamber. After satisfactory root and shoot establishment, the clonal plants were hardened at shade house and open nursery and hardened plants were used for the experiment.

The experiment consists of 4 different spacing Viz., 1.5m X 1.5m (4444 plants ha $\left.{ }^{-1}\right), 2.0 \mathrm{~m} \mathrm{X}$ $2.0 \mathrm{~m}$ (2500 plants $\left.\mathrm{ha}^{-1}\right), 2.0 \mathrm{~m}$ X $2.5 \mathrm{~m}$ (2000 plants $\mathrm{ha}^{-1}$ ) and $3.0 \mathrm{~m} \mathrm{X} 1.5 \mathrm{~m}$ (2200 plants $\mathrm{ha}^{-1}$ ) with respective plants populations were carried out in Randomized Block Design (RBD) and replicated four times. All the plots were raised under micro irrigation system. Biometric observations on growth parameters viz. Plant height $(\mathrm{m})$, girth at breast height $(\mathrm{GBH} ; \mathrm{cm})$, diameter at breast height $(\mathrm{DBH}$; $\mathrm{cm}$ ), tree volume, total biomass (above ground + below ground, t) and light intensity were recorded at 6 (July 2018), 12 (January 2019), 18 (July 2019), 24 (January 2020) and 30 (July 2020) months after planting (MAP).

Total height of the tree from ground level to tip of the main stem was recorded with Haga Altimeter and expressed in meter. All the trees were marked at $1.37 \mathrm{~m}$ above the ground level and the GBH was taken with the help of tailor's tape (Chaturvedi and Khanna, 1984) and expressed in $\mathrm{cm}$. The DBH of the trees 
were arrived by using the formula G/3.14 and expressed in $\mathrm{cm}$.

Tree volume was calculated using the formula Volume $(\mathrm{V})=\square \square \mathrm{X}$ (radius at breast height ${ }^{\text {) }}$ $\mathrm{X}$ height of the tree $\mathrm{X}$ farm factor as proposed by Chaturvedi and Khanna, 1984 and expressed in cubic meter $\left(\mathrm{m}^{3}\right)$. The above ground biomass was estimated by destructive sampling method using mechanical chain saw ((Poulan / Pro, USA).

For below ground biomass estimation, pits were excavated at $1 \mathrm{~m}$ radius for complete recovery of roots and immediately weighed in appropriate spring scale. The light intensity of all spacing was estimated using lux meter. The biometric data obtained at all stages of experiment was statistically processed following Randomized Block Design (RBD) including $\mathrm{F}$ test and ANOVA as proposed by Sheron et al., (1998). To estimate significance of different spacing, treatment means were compared at $\mathrm{p}<0.05$.

\section{Results and Discussion}

\section{Height and GBH}

The present investigation revealed that tree height and GBH of Melia dubia was significantly influenced by different spacing. The mean DBH of trees with increased spacing had a strong positive correlation at $\mathrm{p}=0.05$. However, the mean $\mathrm{DBH}$ at 30 months after planting (MAP) had the trend of maximum $\mathrm{GBH}$ of $17.65 \mathrm{~cm}$ with $\mathrm{T}_{4}(3.0 \mathrm{~m} \mathrm{X}$ $1.5 \mathrm{~m})$, followed by $\mathrm{T}_{2}(2.5 \mathrm{~m} \times 2.0 \mathrm{~m} ; 27.13$ $\mathrm{cm})$ and $\mathrm{T}_{3}(2.0 \mathrm{~m} \times 2.0 \mathrm{~m} ; 26.99)$ treatments, which exhibited statistically on par values. The least GBH of $23.0 \mathrm{~cm}$ was recorded with $\mathrm{T}_{1}(1.5 \mathrm{~m} \times 1.5 \mathrm{~m})$ during the same time. The regression equation developed for the relationship between spacing and $\mathrm{GBH}$ of Melia dubia also evidenced the trend with registering $R^{2}$ value of 0.943 . The maximum height at all the growing period of Melia dubia was recorded with $\mathrm{T}_{4}$, followed by $\mathrm{T}_{3}$, $\mathrm{T}_{2}$ and $\mathrm{T}_{1}$. At $30 \mathrm{MAP}, \mathrm{T}_{4}(3.0 \mathrm{~m} \times 1.5 \mathrm{~m})$ recorded the highest mean height of trees $(8.76 \mathrm{~m})$ and other spacing viz., $\mathrm{T}_{3}(8.68 \mathrm{~m})$, $\mathrm{T}_{2}(8.72 \mathrm{~m})$ and $\mathrm{T}_{1}(8.71 \mathrm{~m})$ were recorded statistically equal heights. The significant variation in GBH and height of Melia dubia plantation with different spacing may be attributed to the limiting factors of moisture light and nutrients. The widely spaced trees tend to effectively capture more sunlight, absorb sufficient moisture and nutrients for their growth (Naji and Sahri, 2012). This can also be related to crown size at lower planting density (Jiang et al., 2007) This association of increased height and GBH with increased spacing is commonly known and has been reported by many authors in various plantation tree crops (Niessan et al., 2001; Prasad et al., 2011 and Andrzej et al., 2018) (Fig. 1).

\section{Stand volume and biomass}

Increase in stand volume and biomass with increasing age of plantation is self explanatory. Various spacing has a significant impact on stand volume and biomass production in Melia dubia plantation. A contrary result of increased stand volume and biomass production at closer spacing plots against lesser height and $\mathrm{DBH}$ in the same plots was obtained in the experiment. Lesser individual tree height $(\mathrm{m})$ and $\mathrm{DBH}(\mathrm{cm})$ were recorded with closer spacing plots and larger stand volume $\left(\mathrm{m}^{3} \mathrm{ha}^{-1}\right)$ and biomass $(\mathrm{t}$ $\mathrm{ha}^{-1}$ ) were recorded with the same plots. At 30 months after planting, the closer spacing of $1.5 \mathrm{~m} \mathrm{X} 1.5 \mathrm{~m}\left(\mathrm{~T}_{1}\right)$ plot recorded mean stand volume of $188.10 \mathrm{~m}^{3} \mathrm{ha}^{-1}$. This was followed by the spacing of $2.0 \mathrm{~m} \mathrm{X} 2.0 \mathrm{~m}\left(\mathrm{~T}_{2}\right)$ with $178.93 \mathrm{~m}^{3} \mathrm{ha}^{-1}$. The least mean stand volume of $153.91 \mathrm{~m}^{3} \mathrm{ha}^{-1}$ was registered with $\mathrm{T}_{3}$ $(2.5 \mathrm{~m} \times 2.0 \mathrm{~m})$. The same trend was obtained with biomass production of Melia dubia 
plantations at all the ages. The highest mean biomass was recorded with closer spacing plot of $\mathrm{T}_{1}$ with $158.21 \mathrm{t} \mathrm{ha}^{-1}$ at 30 months of after planting. The least biomass production was recorded with $\mathrm{T}_{3}$ with $120.70 \mathrm{t} \mathrm{ha}^{-1}$. In our experiment, spacing had different tree densities per unit area viz. $\mathrm{T}_{1}-4444$ trees $\mathrm{ha}^{-1}$, $\mathrm{T}_{2^{-}} 2500$ trees ha ${ }^{-1}, \mathrm{~T}_{3^{-}} 2000$ trees ha ${ }^{-1}$ and $\mathrm{T}_{4}$ - 2222 trees $\mathrm{ha}^{-1}$. The increment in individual tree height and $\mathrm{GBH}$ attributes to wider spacing, but the total stand volume and total biomass production attributes number of trees per unit area, apart from spacing adopted. Although individual tree growth is better in wide spacing plots, the cumulative volume of closer spacing recorded highest volume suggesting a trade- off between individual tree growth and stand volume. The overall divergence in stand volume and biomass production was due to more tree numbers per unit area in lesser spacing which directly influenced in both terms. The regression analysis also supported the present finding of decreased stand volume with wider spacing plantations at $\mathrm{R}^{2}$ value of 0.701. Similar finding was reported in Melia dubia plantation by Prajapathi et al., (2020) (Fig. 24).

\section{Biomass carbon and light intensity}

Assessment of tree plantation stand carbon includes estimation of total stand biomass production. In the present study, we have converted the total biomass production into stand biomass carbon, in order to ensure high carbon stock in short rotation agro- forestry plantations like Melia dubia. The biomass carbon increased with age of plantation. At 30 months after planting, closer spacing of $1.5 \mathrm{~m}$ $\mathrm{X} 1.5 \mathrm{~m}\left(\mathrm{~T}_{1}\right)$ recorded the highest mean biomass carbon of $79.16 \mathrm{t} \mathrm{ha}^{-1}$, followed by $\mathrm{T}_{4}(3.0 \mathrm{~m} \times 1.5 \mathrm{~m})$ with $77.59 \mathrm{t} \mathrm{ha}^{-1}, \mathrm{~T}_{3}(2.5 \mathrm{~m}$ $\mathrm{X} 2.0 \mathrm{~m})$ with $73.46 \mathrm{t} \mathrm{ha}^{-1}$ and $\mathrm{T}_{3}(2.5 \mathrm{~m} \mathrm{X}$ $2.0 \mathrm{~m})$ with $60.35 \mathrm{t} \mathrm{ha}^{-1}$. At initial stage of planting, significant difference in carbon stock was found due to variation in growth of individual plants. The wider spacing plots registered lower carbon stock due to limitation in number of plants per unit area and in turn carbon uptake. At the age of 30 months after planting, there was no significant difference in biomass carbon stock between the spacing, and it can be justified with positive influence of growth and increased stand volume over time in the closer spacing plots. This can be explained as in closer spacing trees, even more carbon is allocated in stems, biomass allocated to crown decreases with age due to natural pruning of lower branches and thus reduces the carbon sink potential. Therefore, with the increment of plantation age, no significant stand biomass carbon will be found between wider spacing and closer spacing plantations (Pasquale et al., 2015).

The light intensity plays important role in growth and development of Melia dubia. The relationship between mean light intensity and age of plantation measured at $6,12,18,24$ and 30 months showed negative correlation (Fig. 5). The $\mathrm{R}^{2}$ value for the regression line is 0.618 (Fig. 6). This negative correlation is self explanatory as the age progresses, development of crop canopy resulted in lesser light intensity. However, the higher light intensity was recorded with wide spacing plots which was significant over the closer spacing plots.

In conclusion, the tree species Melia dubia has been cultivated in Tamil Nadu state extensively as industrial plantations mainly for pulpwood supply (pulp and paper industries) and timber supply (plywood/ sawmill industries). The size and quality of wood for both the industries basically differ in their requirement. Pulp and paper industry requires a minimum of $5 \mathrm{~cm}$ girth at lower end and almost 95 percent of the stem can be consumed for pulping. Whereas, the plywood industries require a minimum of $65 \mathrm{~cm}$ girth for manufacturing products. 
Table.1 Effect of various spacing on height $(\mathrm{m})$ and $\mathrm{GBH}(\mathrm{cm})$ of Melia dubia at different growth stages

\begin{tabular}{|c|c|c|c|c|c|c|c|c|c|c|}
\hline \multirow[t]{2}{*}{ Spacing } & \multicolumn{5}{|c|}{ Height (m) } & \multicolumn{5}{|c|}{ GBH (cm) } \\
\hline & 6 MAP & $\begin{array}{c}12 \\
\text { MAP }\end{array}$ & $\begin{array}{c}18 \\
\text { MAP }\end{array}$ & $\begin{array}{c}24 \\
\text { MAP }\end{array}$ & $\begin{array}{c}30 \\
\text { MAP }\end{array}$ & 6 MAP & $\begin{array}{c}12 \\
\text { MAP }\end{array}$ & $\begin{array}{c}18 \\
\text { MAP }\end{array}$ & $\begin{array}{c}24 \\
\text { MAP }\end{array}$ & $\begin{array}{c}30 \\
\text { MAP }\end{array}$ \\
\hline $\mathrm{T} 1$ (1.5mX1.5m) & 3.50 & 7.08 & 7.48 & 8.43 & 8.71 & 10.48 & 19.23 & 20.50 & 22.50 & 23.00 \\
\hline $\mathrm{T} 2(2.0 \mathrm{mX} 2.0 \mathrm{~m})$ & 3.79 & 7.01 & 7.83 & 8.38 & 8.72 & 11.86 & 22.55 & 23.95 & 26.57 & 27.13 \\
\hline $\mathrm{T3}(2.5 \mathrm{mX} 2.0 \mathrm{~m})$ & 3.83 & 7.06 & 7.90 & 8.38 & 8.68 & 12.08 & 22.56 & 24.38 & 26.40 & 26.99 \\
\hline $\mathrm{T} 4(3.0 \mathrm{mX1} 1.5 \mathrm{~m})$ & 4.17 & 7.33 & 8.12 & 8.76 & 9.05 & 12.95 & 23.42 & 25.66 & 27.20 & 27.65 \\
\hline S.E. \pm & 0.04 & 0.11 & 0.16 & 0.09 & 0.09 & 1.97 & 0.68 & 0.79 & 0.90 & 0.96 \\
\hline C.D. $(p=0.05)$ & 0.12 & 0.30 & 0.29 & 0.26 & 0.25 & 5.57 & 1.91 & 2.33 & 2.54 & 2.70 \\
\hline
\end{tabular}

Table.2 Effect of various spacing on stand volume $\left(\mathrm{m}^{3} / \mathrm{ha}\right)$ and biomass $(\mathrm{t} / \mathrm{ha})$ of Melia dubia at different growth stages

\begin{tabular}{|c|c|c|c|c|c|c|c|c|c|c|}
\hline \multirow[t]{2}{*}{ Spacing } & \multicolumn{5}{|c|}{ Stand tree volume $\left(\mathrm{m}^{3} / \mathrm{ha}\right)$} & \multicolumn{5}{|c|}{ Biomass (t/ha) } \\
\hline & $\begin{array}{c}6 \\
\text { MAP }\end{array}$ & 12 MAP & 18 MAP & 24 MAP & 30 MAP & $\stackrel{6}{\text { MAP }}$ & $\begin{array}{c}12 \\
\text { MAP }\end{array}$ & $\begin{array}{c}18 \\
\text { MAP }\end{array}$ & 24 MAP & 30 MAP \\
\hline $\mathrm{T} 1$ (1.5mX1.5m) & 60.81 & 106.80 & 144.44 & 178.38 & 188.10 & 9.77 & 23.87 & 78.80 & 134.48 & 158.21 \\
\hline $\mathrm{T} 2(2.0 \mathrm{mX} 2.0 \mathrm{~m})$ & 46.12 & 94.60 & 137.56 & 169.02 & 178.93 & 9.11 & 22.17 & 71.50 & 124.84 & 146.88 \\
\hline $\mathrm{T} 3(2.5 \mathrm{mX2.0m})$ & 33.21 & 84.23 & 121.26 & 144.31 & 153.91 & 7.49 & 18.22 & 64.50 & 102.60 & 120.70 \\
\hline $\mathrm{T} 4(3.0 \mathrm{mX1} .5 \mathrm{~m})$ & 45.28 & 102.00 & 139.00 & 159.67 & 167.00 & 9.55 & 23.42 & 76.40 & 131.89 & 155.17 \\
\hline S.E. \pm & 3.11 & 5.63 & 7.71 & 6.59 & 6.81 & 0.50 & 1.47 & 5.18 & 4.75 & 3.82 \\
\hline C.D. $(p=0.05)$ & 8.74 & 15.69 & 21.71 & 18.49 & 19.14 & 1.41 & 4.13 & 14.56 & 13.35 & 10.87 \\
\hline
\end{tabular}

Table.3 Effect of various spacing on Biomass carbon ( $\mathrm{t} / \mathrm{ha}$ ) and light intensity (lux) of Melia dubia at different growth stages

\begin{tabular}{|c|c|c|c|c|c|c|c|c|c|c|}
\hline \multirow[t]{2}{*}{ Spacing } & \multicolumn{5}{|c|}{ Biomass carbon ( $t /$ ha) } & \multicolumn{5}{|c|}{ Light intensity (lux) } \\
\hline & $\begin{array}{c}6 \\
\text { MAP }\end{array}$ & 12 MAP & 18 MAP & 24 MAP & 30 MAP & 6 MAP & $\begin{array}{c}12 \\
\text { MAP }\end{array}$ & $\begin{array}{c}18 \\
\text { MAP }\end{array}$ & $\begin{array}{c}24 \\
\text { MAP }\end{array}$ & $\begin{array}{c}30 \\
\text { MAP }\end{array}$ \\
\hline T1 (1.5mX1.5m) & 4.90 & 11.94 & 39.43 & 67.24 & 79.16 & 561.33 & 462.00 & 352.00 & 283.33 & 208.67 \\
\hline $\mathrm{T} 2(2.0 \mathrm{mX} 2.0 \mathrm{~m})$ & 4.56 & 11.10 & 35.76 & 62.42 & 73.46 & 696.00 & 622.33 & 510.67 & 383.67 & 271.67 \\
\hline $\mathrm{T3}(2.5 \mathrm{mX2.0m})$ & 3.76 & 9.11 & 32.23 & 51.30 & 60.35 & 753.00 & 671.00 & 521.33 & 385.00 & 293.67 \\
\hline $\mathrm{T} 4(3.0 \mathrm{mX} 1.5 \mathrm{~m})$ & 4.78 & 11.71 & 38.25 & 65.95 & 77.59 & 879.00 & 764.33 & 643.67 & 508.67 & 372.67 \\
\hline S.E. \pm & 0.25 & 0.73 & 1.59 & 1.38 & 2.94 & 6.24 & 5.63 & 12.03 & 7.58 & 4.08 \\
\hline C.D. $(p=0.05)$ & 0.71 & 2.07 & 4.47 & 3.90 & 8.26 & 17.64 & 15.90 & 33.96 & 21.39 & 11.52 \\
\hline
\end{tabular}


Fig.1 Effect of different spacing on GBH (cm) of Melia dubia

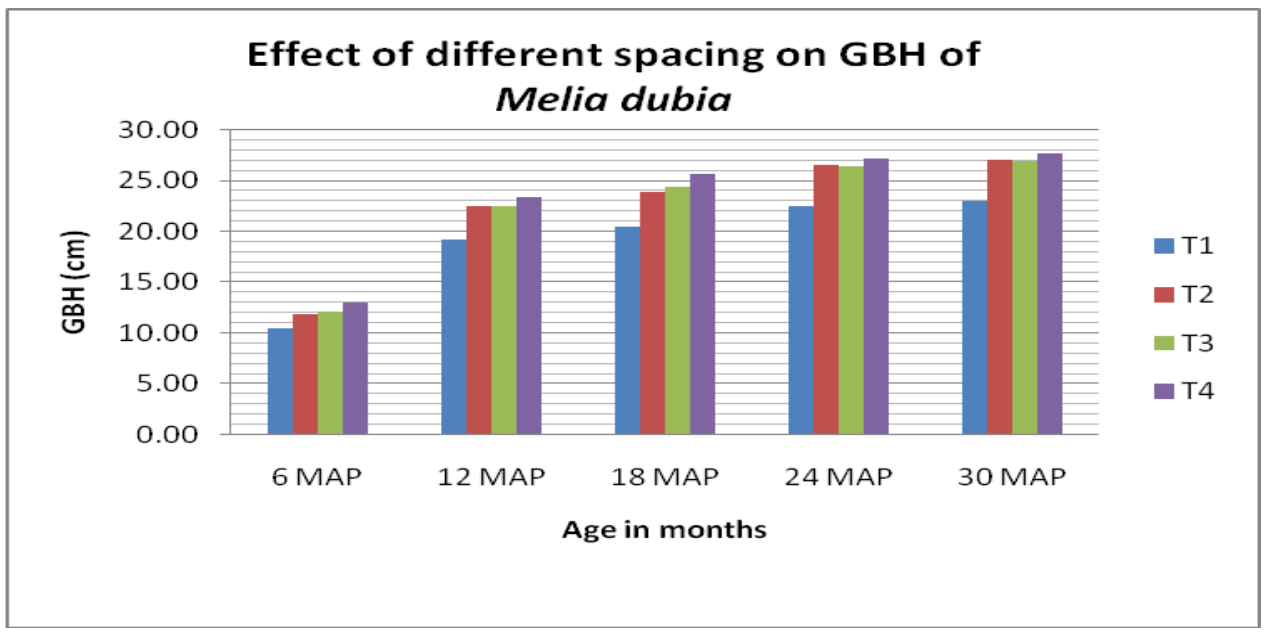

Fig.2 The relationship between different spacing and mean DBH $(\mathrm{cm})$ on Melia dubia plantation during 30 months after planting

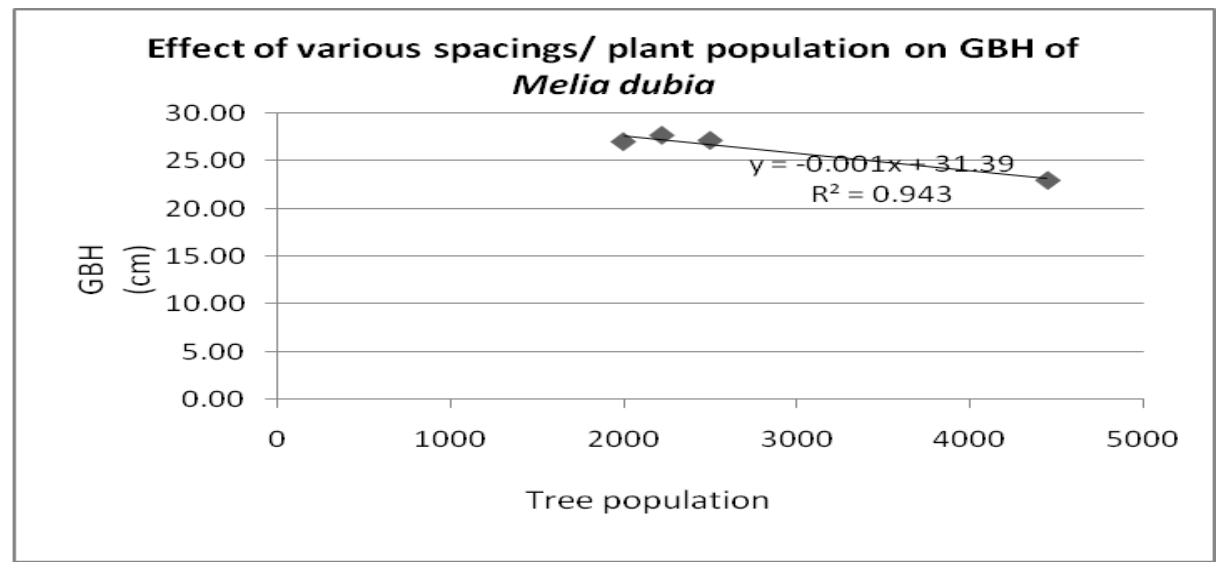

Fig.3 Effect of different spacing on stand volume $\left(\mathrm{m}^{3} / \mathrm{ha}\right)$ of Melia dubia

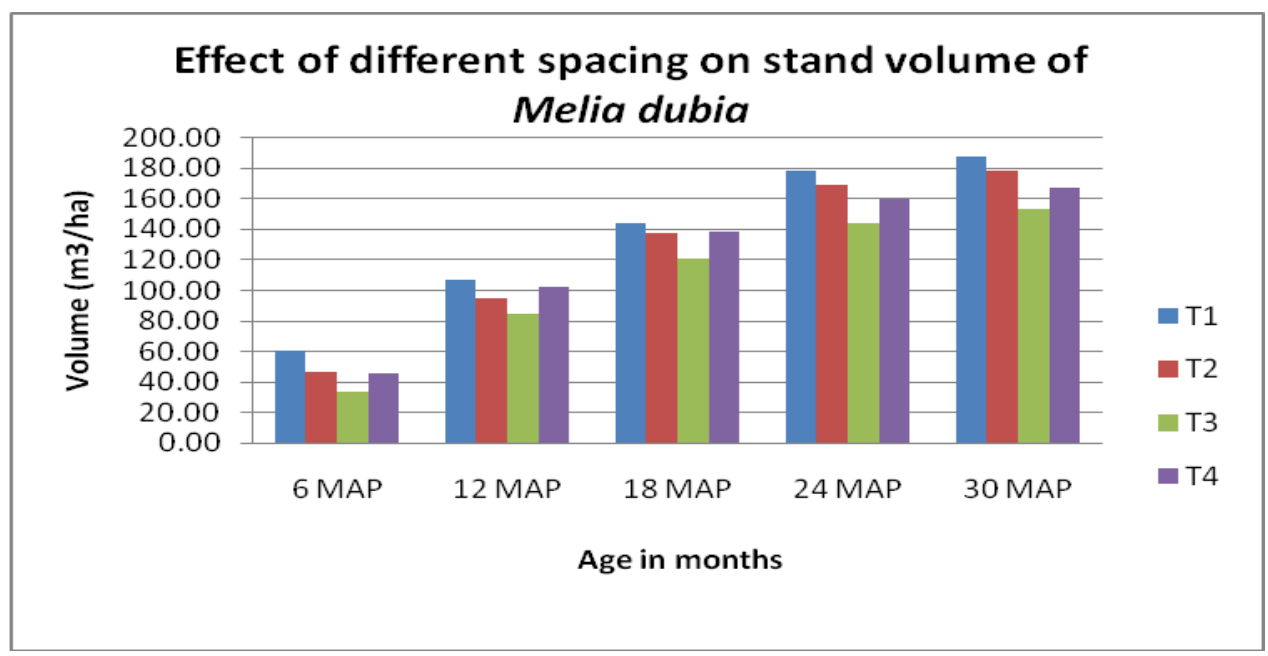


Fig.4 Effect of different spacing on biomass (t/ha) of Melia dubia

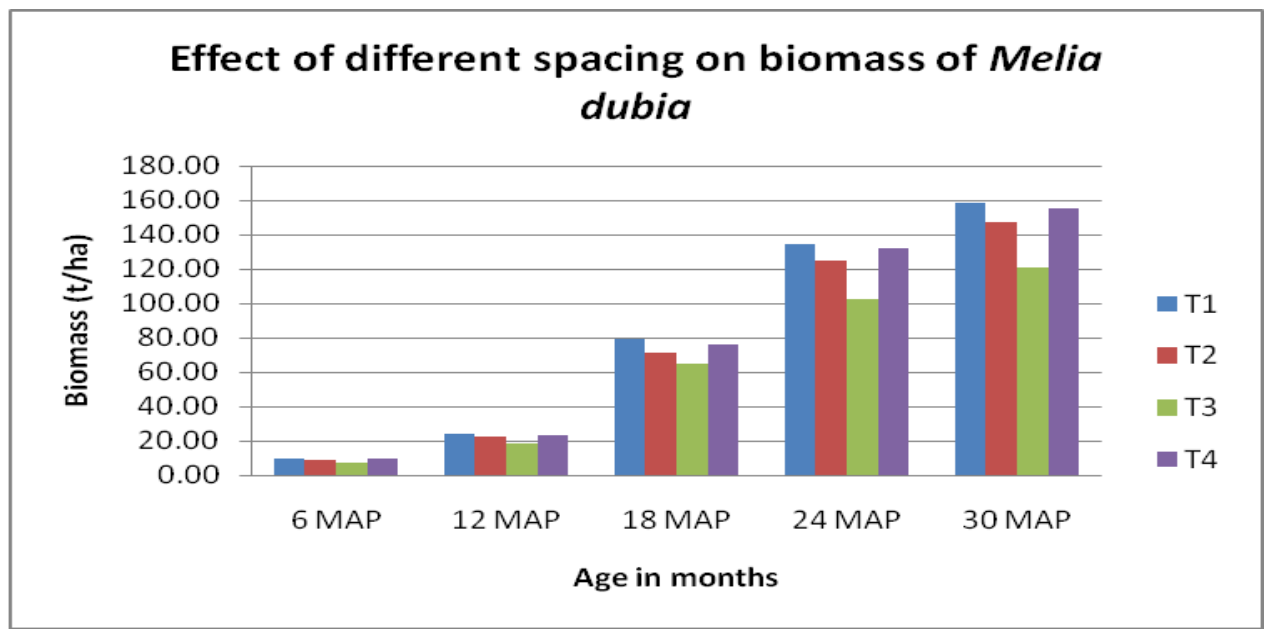

Fig.5 The relationship between different spacing and mean stand volume $\left(\mathrm{m}^{3} \mathrm{ha}^{-1}\right)$ on Melia dubia plantation during 30 months after planting

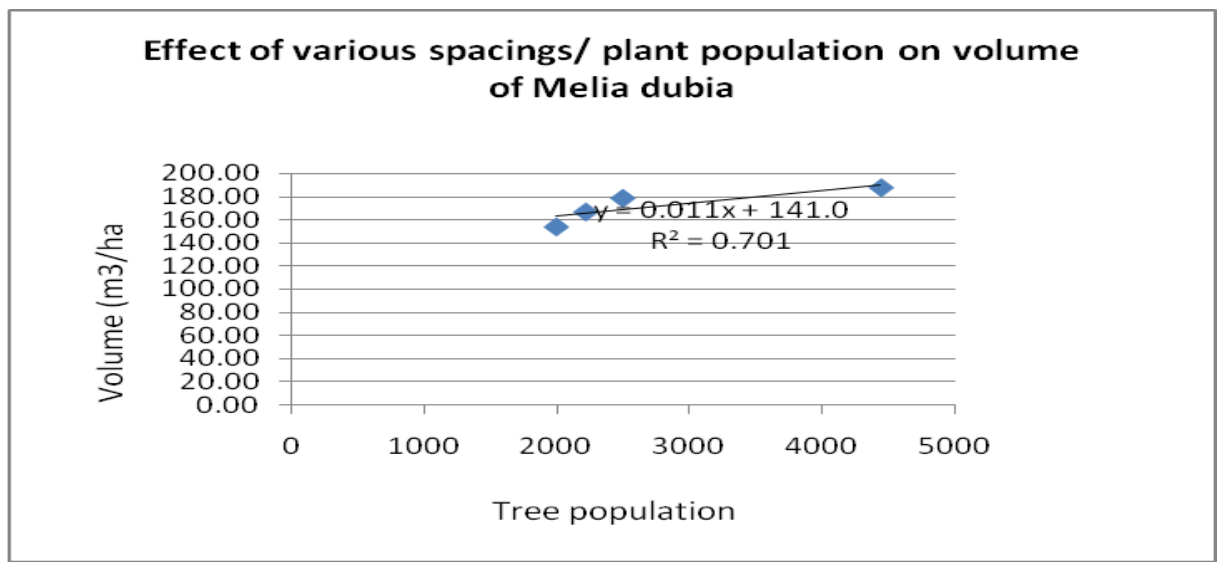

Fig.6 Effect of different spacing on light intensity (lux) of Melia dubia

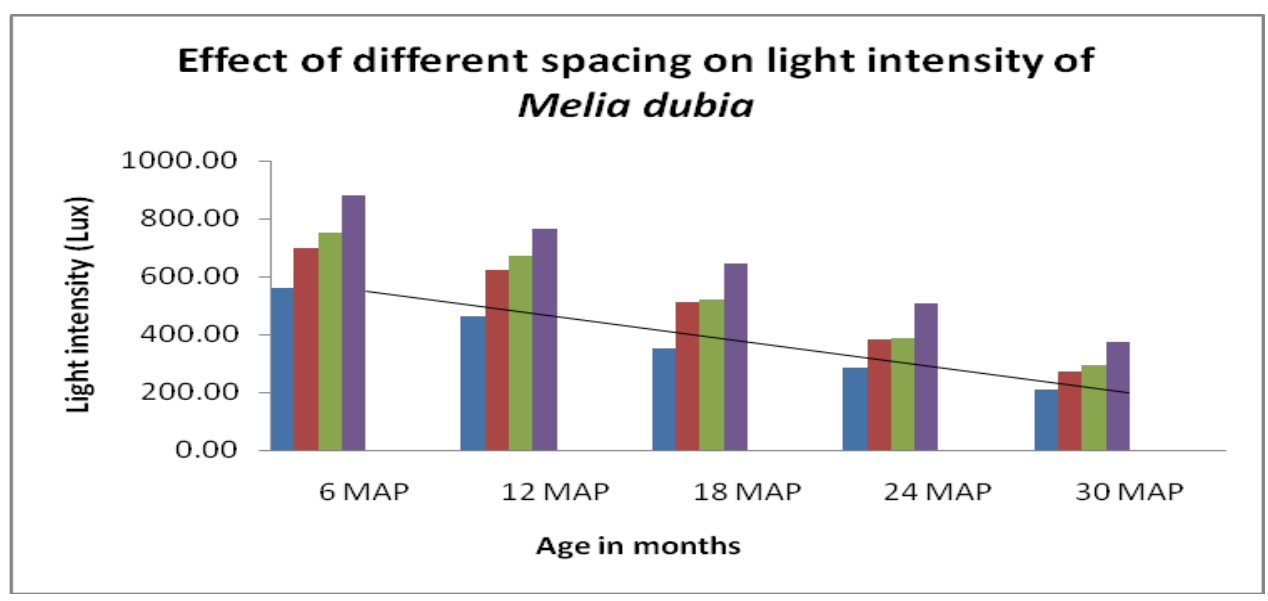


Fig.7 The relationship between different spacing and mean light intensity (lux) on Melia dubia plantation during 30 months after planting

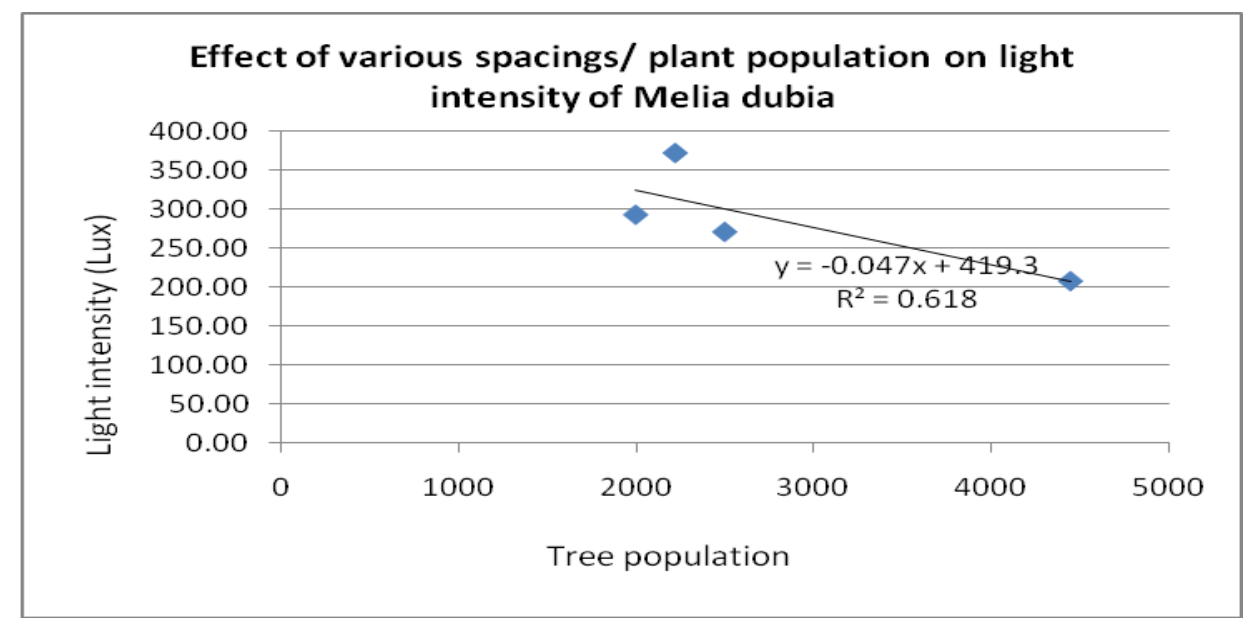

Tree dimensions are the most important factor affecting the value of plywood/ sawmill timber. The large the diameter, the higher the selling price obtained. For plywood/ sawmill wood production, maintaining fewer trees per unit area (wider spacing) is sufficient to obtain a given volume of wood. On contrary, pulp and paper industries require large volume of wood per unit area with high cellulose content. According to Andrzej et al., (2018), closer spacing/ high density plantations has a bi-directional impact. On the one hand, trees with closer spacing may produce better quality wood due to slower growth and smaller knots whereas larger spacing decreases stand density, often eliminates low quality trees.

The present study was aimed at standardization of spacing for Melia dubia agro-forestry plantation to increase wood Andrzej Wegiel, Mariusz Bembenek, Agnieszka and Piotr S. Mederski. 2018. Relationship between stand density and value of timber assortments: a case study for scots pine stands in north-western Poland. New Zealand Journal of Forestry Science. https://doi.org/10.1186/s40490-018- volume per unit area pertaining to pulpwood production. The results showed a strong correlation between spacing and stand volume of Melia dubia and indicates that for raising short rotation pulpwood plantation, adopting closer spacing of $1.5 \mathrm{~m} \mathrm{X} 1.5 \mathrm{~m}$ with 4444 trees $\mathrm{ha}^{-1}$ and with a spacing of $2.0 \mathrm{~m} \mathrm{X} 2.0 \mathrm{~m}$ with 2500 trees $^{-1}$ yielded similar results with highest stand volume.

Thus the present investigation clearly indicates that in Melia dubia plantations to reduce the cost of cultivation and to enable intercropping in the first 6 months of age along with higher wood volume per unit area, adopting $2.0 \mathrm{~m} \mathrm{X} 2.0 \mathrm{~m}$ spacing with total population of 2500 trees $\mathrm{ha}^{-1}$ can be recommended.

\section{References}

0117-7.

Chaturvedi, A.N. and Khanna, I.S. 1984. Forest mensuration, International Book distributers, Dehradun, Uttarakhand (India).

Chauhan, R.S., D.B. Jadeja, N.S. Thakur, S.K. Jha and Sankanur, M.S. 2018. Selection of Candidate Plus Trees (CPTs) of Malabar Neem (Melia dubia 
Cav.) for Enhancement of Farm Productivity in South Gujarat. Int.J.Curr.Microbiol.App.Sci. 7(05): 3582-3592.

H.Y. Patil, G. Karatangi kirankumar and S.M. Mutanal. 2017. Growth and productivity of Melia dubia under different plant density. International Journal of Forestry and Crop Improvement. 8(1): 30-33.

Jiang, Z.H., X.Q. Wang, B.H. Fei, H.Q. Ren and Liu, X.E. 2007. Effect of stand and tree attributes on growth and wood quality characteristics from a spacing trial with Populous xiahori. Ann.Forest Sci. 64: 807-814.

Naji, H.R. and Sahri, M.H. 2012. Intra- and inter-clonal tree growth variations of Hevea brasilensis. J. Forestry Res. 23(3); 429-434

Nieeen, T.M., Midmore, D.J. and Keelar,A.G. 2001. Biophysical and economical tradeoffs of intercropping timber with food crops in the Philippine uplands. Agricultural systems. 67:49-69.

Parthiban KT, Bharathi AK, Seenivasan R, Kamala K, Rao MG (2009) Integrating Melia dubia in agroforestry farms as an alternate pulpwood species. APA News 34: 3-4.

Pasquale A Marziliano, Vittoria Coletta, Giuliano Menguzatto, Antonino Nicolaci, Gaetano Pellicone and Antonella Veltri. 2015. Effects of planting density on the distribution of biomass in a douglas-fir plantation in southern Italy. Biogeosciences ane Forestry. 8: 368-376.

Prajapati, D.R., N.S. Thakur, R.P. Gunaga,
V.R. Patil, R.J. Mevada and D.C. Bhuva. 2020. Growth performance of Melia dubia in sole and Melia dubiasorghum sudan grass silvi- pasture systems: sorghum Sudan grass intercropping implications. Int.J.Curr. Microbiol. App.Sci. 9(4): 726-732.

Prasad, J.V.N.S., Korwar, G.R., Rao, K.V. and Mandal, U. 2011. Optimum stand density of Leucaena leucocephala for wood production in Andra Pradesh, Southern India. Biom. Bioen., 35(1): 227-235.

Saravanan V, Parthiban KT, Kumar P, Marimuthu P (2013) Wood characterization studies on Melia dubia Cav for pulp and paper industry at different age gradation. Research Journal of Recent Science 2:183-188.

Sheron OP, Tonk DS, Kaushik LS, Hasija RC, Pannu RS (1998) Statistical Software Package for Agricultural Research Workers. In: Hooda DS, Hasija RC. (Eds) Recent Advances in information theory, Statistics \& Computer Applications by Department of Mathematics Statistics, CCS HAU, Hisar, India, Pp. 139-143.

Tak, A., and Jindal, S. K. 2014. Reproductive biology of Acacia Senegal (L.) Willd. International Journal of Advances in Research. 2(5): 498-502

Thakur, N S., Dinesh Kumar, R P Gunaga and Susheel Singh. 2017. Allelopathic propensity of the aqueous leaf extract and leaf litter of Melia dubia cav. on pulse crops. Journal of Experimental Biology and Agricultural Sciences. 5(5): 644-655.

\section{How to cite this article:}

Jayakumar, K. and Sudhakar, P. 2020. Standardization of Plant Geometry for Productivity Enhancement of Melia dubia Cav. under Agro-Forestry Pulpwood Plantation. Int.J.Curr.Microbiol.App.Sci. 9(12): 937-945. doi: https://doi.org/10.20546/ijcmas.2020.912.113 